\title{
AN INVASION OF FOREST TENT CATERPILLARS
}

EVELYN M. CASSON, Box 11, Medstead, Saskatchewan, SOM 1W0.

My farm buildings are situated in a thick growth of poplars (mostly trembling aspen), with an undergrowth of hazelnut, rose, high bush cranberry, alders, and some saskatoons, chokecherry and pin cherry. Last year I noticed that some of these trees, at some distance from the yard, had lost their leaves through the spread of the forest tent caterpillar, but the caterpillars did not come near the buildings. This spring, however, I began to notice trees closer home with their leaves stripped. Walking out from the yard one day, I came across a poplar with its trunk thick with small, black caterpillars crawling upward. I rushed home for the spray gun and sprayed the tree trunk as high as I could reach, but on looking around I saw that all the trees nearby were covered with the caterpillars. Then I realized it would be of no use to try to spray by hand.

About 12 June I began to see caterpillars coming into the yard. At first there were only a few, which I dispatched as quickly as possible, but the trees and shrubs in the yard soon began to lose their leaves, until all were quite bare. By 15 June, the woods were full of rapidly growing caterpillars, eating voraciously and crawling everywhere. I sprayed and sprayed to keep them off the flower beds and vegetable garden. They began crawling up the walls of the buildings, and would manage to creep up a foot or so on the slippery siding of the house before falling down again. Others followed and fell on top of those below, and soon there heaps of them, some dead and other: alive. On 19 June, I hauled awa seven wheelbarrow loads and poure gasoline on them to burn them.

By this time, leaves and blossom around the yard were all eaten. The crabapples, mountain ash, rose bushes, willows, Russian almond and cherries were mere bare sticks where a week before they were beau tiful in full leaf and bloom.

In the front yard were two larg Manitoba maple trees. The cater pillars moved into them, but did no eat the leaves. Instead, they climber up the trunks and branches and ther began to fall to the ground where the piled up in heaps. A total of 20 wheel barrow loads were hauled away.

On 20 June, a plane was hired t spray. The spray killed hundreds o caterpillars, but more and more came. It was horrible to walk unde the trees as there were webs a around and caterpillars were drop ping everywhere. As we looked west ward through the denuded forest a sunset, the trees appeared to b draped in a beautiful silken veil. Thei branches were black with clustere caterpillars and looked like hug black snakes writhing up into the air

On 22 June, the plane sprayes again, and now we began to feel tha the caterpillars would be going int the cocoon stage. There were sti hundreds underfoot as one walked in the yard, and the wheels of cars driv ing in could be heard crunching ove them. By the end of June, the cater pillars were going into the pupa stag 


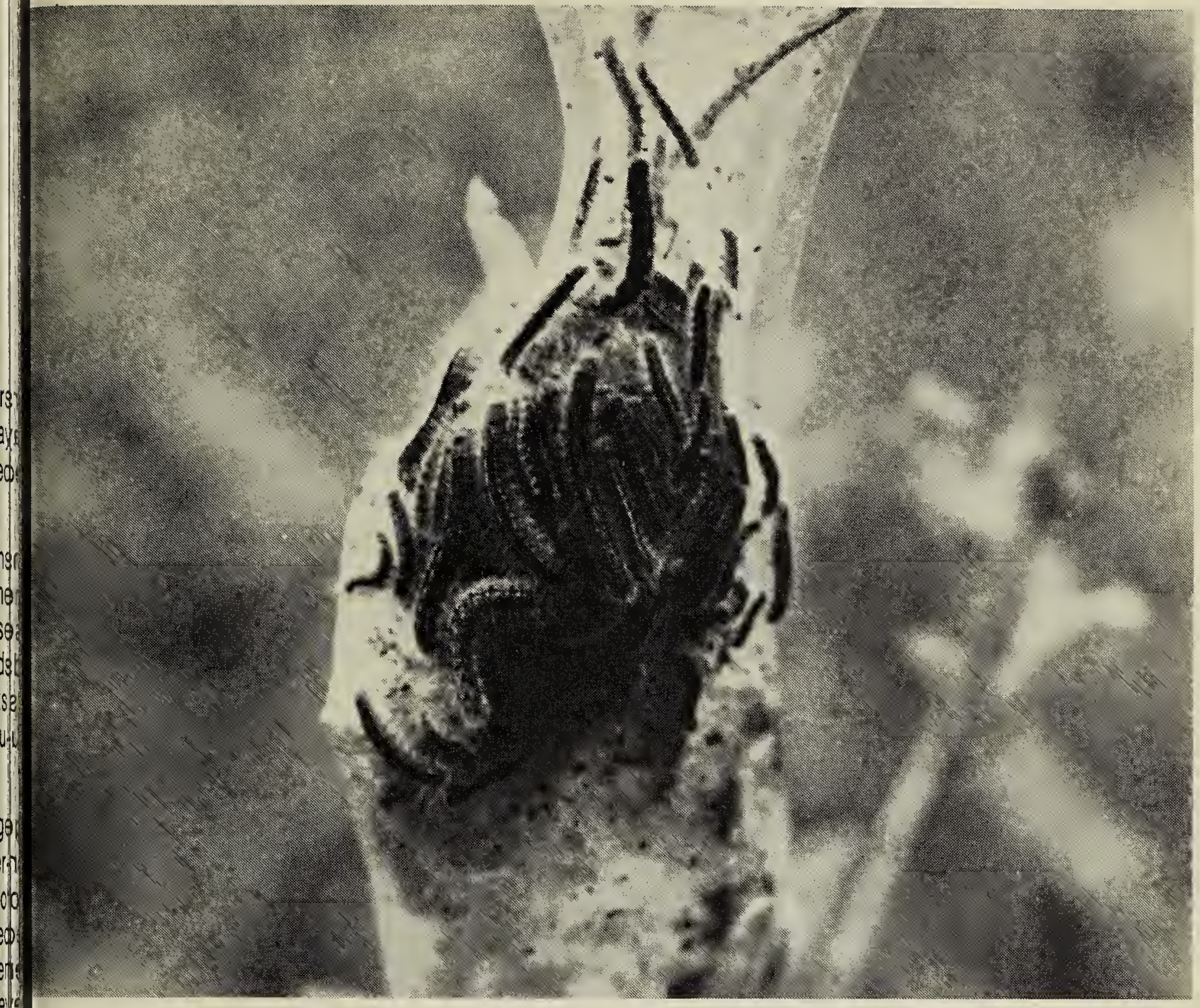

nd the trees and bushes across the buntry were loaded with their white, izzy cocoons.

Ten days to two weeks later the tanbloured moths began to emerge, hd early in the morning the poles of e yard lights would be covered with oths resting in the warm sunlight. his was a boon for the busy little arn swallows and sparrows with milies of nestlings to feed.

Now, where the trees had stood are and gray, a soft green tint began show, as if spring was just beginng. Sure enough, new baby leaves ere opening, and soon the forest as green again. Now on 14 eptember the maple leaves (which ere not eaten by the caterpillars) are turning yellow and beginning to fall, but the young poplar leaves are still green and no sign of ripening and changing colour is seen. This probably means that the leaves have not matured.

The eggs of the forest tent caterpillar are laid in bands around the branches of the trees and these should be cut open in the late fall when the leaves have fallen.

As an outbreak of these caterpillars can last from three to six years we will probably be visited by them again next year. So let us hope that we have plenty of flesh flies, the major parasite which preys on the forest tent caterpillar. 